\title{
Residual amino acid fluxes in Kiel Bight - February to June 1980
}

\author{
Gerd Liebezeit", Marion Schumann“” \& Friedrich Bohde ${ }^{\cdots}$
}

Institut für Meereskunde, Düsternbrooker Weg 20, D-2300 Kiel, Federal Republic of Germany

\begin{abstract}
Residual amino acid fluxes were determined at $2 \mathrm{~d}$ sampling intervals at $20 \mathrm{~m}$ water depth in Kiel Bight from February to June 1980. Three developmental stages can be distinguished - a winter period, the spring bloom sedimentation, and the summer maturation period. Absolute fluxes were highest during the sedimentation of the diatom spring bloom and similarly low for winter and summer situations. The relative contributions of amino acids to the total organic carbon and nitrogen fluxes indicate that the particulate material of the spring bloom and the summer sedimentation contains high amounts of amino acids. This implies that despite the low absolute flux during summer, material of high nutritional quality reaches the sea floor
\end{abstract}

\section{INTRODUCTION}

Boreal ecosystems exhibit distinct annual cycles in primary and secondary production as well as in sedimentation of particulate organic matter (Smetacek et al. 1984). The latter process links pelagic and benthic biota and represents the major food source for benthic organisms. Generally, sedimentation follows a similar annual pattern as primary production, even in deep sea environments (e.g. Deuser \& Ross 1980, Billett et al. 1983, Lampitt 1985).

For our study area - Kiel Bight - the close connection of production/sedimentation processes with abiotic features such as density stratification is a well-established fact, as summarized by Smetacek et al. (1984).

Whereas fluxes of particulate organic matter in Kiel Bight are generally well characterized in terms of total carbon and nitrogen, phytoplankton carbon, and total chlorophylls, data on fluxes of individual compounds are sparse. Hendrikson (1976) fractionated the total organic carbon pool into proteins, carbohydrates, lipids, and humic acids. However, only class reactions were employed and thus no information on the composition of the individual classes is available. Detailed chemical analysis of trap derived particulate material,

\footnotetext{
Present addresses:

Geologisch-Paläontologisches Institut, Bundesstraße 55, D-2000 Hamburg 13, Federal Republic of Germany

" Amtsverwaltung, 2303 Raisdorf, Federal Republic of Germany

'. R. R. 3, Box 246, Tipton, Iowa 52772, USA
}

on the other hand, is not only restricted to a determination of the contribution of individual compounds to total mass flux but also allows an assessment of the origin and nutritional value of this material (e.g. Lee \& Cronin 1982, 1984, Lee et al. 1983, Ittekott et al, 1984 a, b)

In shallow water environments, sedimentation of particulate matter occurs in much shorter time spans than in the deep sea. Thus, a higher temporal resolution is required here to allow connection of sedimentation events with processes in the euphotic zone. In the present paper, data on the flux and composition of residual amino acids at $20 \mathrm{~m}$ water depth in Kiel Bight are given for (mainly) 2 d sampling intervals and discussed in relation to biological and hydrographical parameters.

\section{MATERIAL AND METHODS}

The multisample sediment trap employed has been described in detail by Zeitzschel et al. (1978). Traps were deployed from February to June 1980 in the 'Hausgarten' area of Kiel Bight at $20 \mathrm{~m}$ water depth. Sample cups were changed every 2 nd day. However, especially for the winter period, samples were occasionally pooled to obtain sufficient material for analysis.

After retrieval and straining through $300 \mu \mathrm{m}$ gauze the sedimented material was homogenously suspended in artificial seawater and subsamples filtered through precombusted $\left(450^{\circ} \mathrm{C}\right.$ overnight) $\mathrm{GF} / \mathrm{C}$ filters. 
After sequential extraction with chloroform/methanol, hot water, and $2 \mathrm{~N} \mathrm{HCl}$, the remaining particulate material was hydrolysed with $4.6 \mathrm{~N} \mathrm{HCl}$ for $12 \mathrm{~h}$ at $110^{\circ} \mathrm{C}$ under nitrogen. After $\mathrm{pH}$ adjustment to 11.5 (Liebezeit \& Dawson 1981) amino acids were reacted with o-phthalaldehyde/mercaptoethanol and the isoindoles formed separated by high performance liquid chromatography as described by Dawson \& Liebezeit (1983).

Particulate organic carbon (POC) and nitrogen (PON) were determined on a Hewlett Packard 185 B CHN Analyser after treatment of the filters with dilute hydrochloric acid. Chlorophyll $a$ and phaeopigment contents were determined as recommended by Edler (1979). Pigment concentrations were calculated according to Lorenzen (1967) and the values given chlorophyll a equivalents. POC, PON, and pigment data were taken from Peinert et al. (1982).

Since only 1 filter was available for the analysis of a number of compound classes (lipids, reserve polymers, carbohydrates, and amino acids), losses in the amino acid fraction occurred. These have been estimated by independent analysis of extracts and comparison to non-preextracted material. Lipid-associated proteins extractable with chloroform/methanol accounted for $1.9 \pm 0.7 \%(n=5)$ of total amino acids whereas amino acids extractable with hot water represented $11.2 \pm$ $10.6 \%(n=6)$ (Schumann 1983). Similarly, Bolter \& Dawson (1982) found $16.3 \pm 5.7 \%$ of total amino acids to be water extractable for an Antarctic Phaeocystis bloom. Compounds released after $2 \mathrm{~N} \mathrm{HCl}$ hydrolysis $\left(110^{\circ} \mathrm{C}, 3 \mathrm{~h}\right)$ made up 27 to $34 \%$ of total amino acids (Liebezeit unpubl.). It is likely that some overlap in the water and $2 \mathrm{~N} \mathrm{HCl}$ extracts occurred, i.e. the acid extract will also contain the water extractable compounds. We therefore have adopted a value of $25 \%$ of total amino acids being lost during sample pretreatment as a conservative figure. The remaining $75 \%$ most probably represent polymers serving structural functions and the term residual amino acids (RAA) has been coined for this fraction (Liebezeit 1985a).

\section{RESULTS AND DISCUSSION}

\section{General background}

The succession of phyto- and zooplankton over the annual cycle in relation to meteorological, hydrographical and chemical parameters in Kiel Bight is a well-researched phenomenon (Smetacek et al. 1984). Details on plankton species composition and other pertinent background information for the present investigation period - February to June 1980 - have been presented by Peinert et al. (1982). Briefly, the above authors distinguish between 3 stages: (1) a winter period (Feb to mid Mar), (2) the spring bloom (mid Mar to early Apr) and (3) a maturation period of the pelagic system (early Apr to Jun).

During winter, phytoplankton was sparse with a small nanoflagellate population present. The spring bloom was dominated by Detonula confervacea, a small bacillariophycea. A storm around March 20 interrupted spring bloom growth for a few days and led to resuspension of surface sediments. After sedimentation of the bloom by early April, primary productivity increased again. Two distinct production peaks were encountered, the first in the second half of April and the second in late May. Whereas the first was caused by small dinoflagellates of the Gymnodinium type the second was due to a mixed population of Mesodinium rubrum, Dinophysis norwegica, D. acuminata and small dinoflagellates.

\section{Amino acid fluxes}

The 3 stages described above are clearly evident in the total amino acid carbon (AA-C) fluxes as well as in the contributions of these compounds to the total organic carbon (TOC) and nitrogen (TON) fluxes (Fig. 1, 2; Table 1). During winter, both total and relative

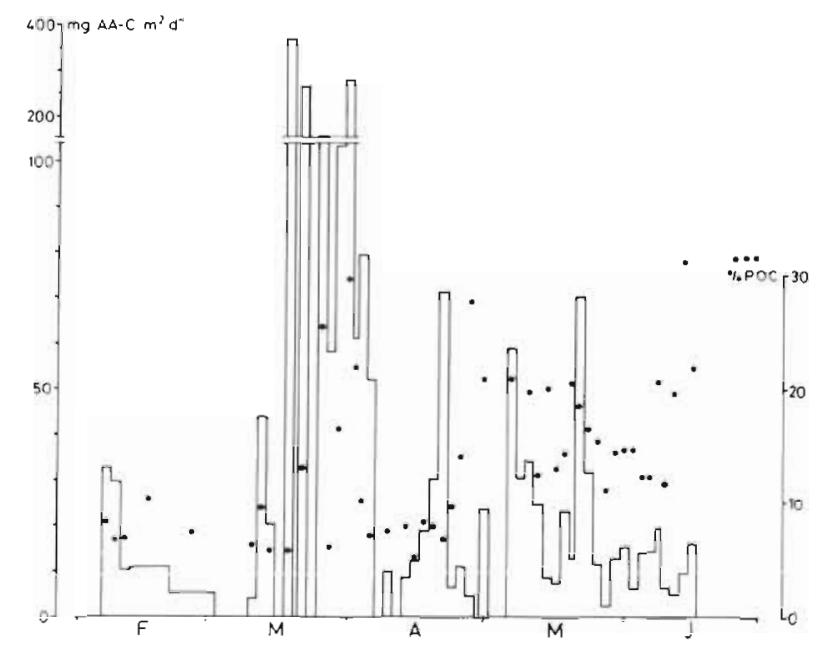

Fig. 1. Absolute (bars) and relative (dots) amino acid carbon fluxes from February to June 1980 in Kiel Bight

fluxes are low. The high contribution of glycine indicates the refractory nature of the particulate material trapped (Gagosian \& Stuermer 1977).

During sedimentation of the spring bloom absolute fluxes decreased from 369 (maximum in resettling of sediment) on March 21 to $52 \mathrm{mg} A \mathrm{~A}-\mathrm{C} \mathrm{m}^{-2} \mathrm{~d}^{-1}$ with a second maximum at the end of March/beginning of 
April (maximum in bloom sedimentation: Fig. 1). The contributions to the TOC and TON fluxes were variable thus reflecting different contributions of sedimentary organic matter. Low values as found from March 18 to 20 (5.8\% TOC) are connected with sediment derived organic material whereas the higher values

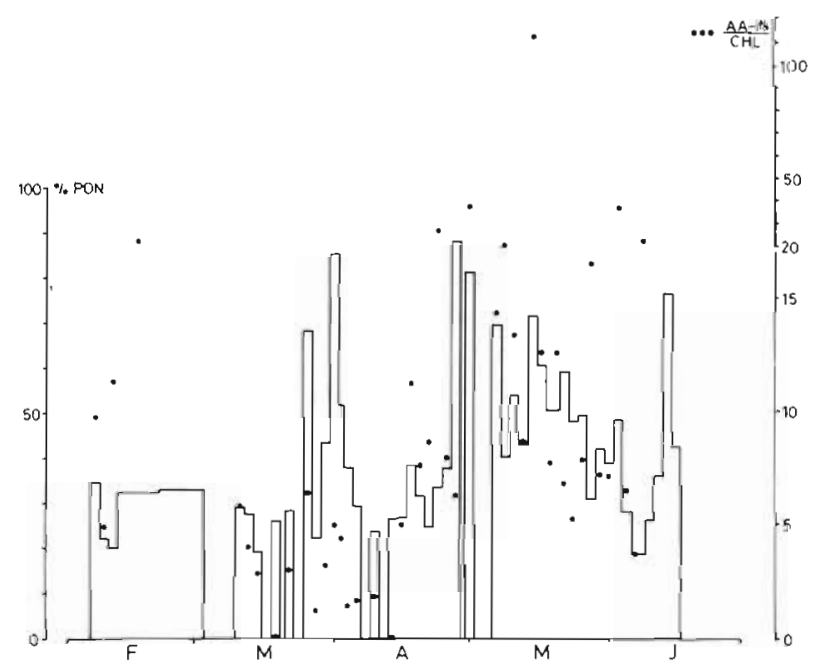

Fig. 2. Relative amino acid nitrogen fluxes (bars) and amino acid nitrogen/chlorophyll ratios (dots) from February to June 1980 in Kiel Bight

encountered later are well within the range reported for freshly produced material (Lee \& Cronin 1982, Liebezeit 1985a).

During the summer period, mean amino acid sedimentation decreased to winter values. The blooms of dinoflagellates and Mesodinium rubrum are, however, clearly discernible (Fig. 1, 2). Although primary production during these blooms was higher than during the spring bloom (Peinert et al. 1982) the AA-C sedimentation is considerably lower (Fig. 1). This is presumably due to the presence of a larger zooplankton population resulting in increased pelagic recycling. Any contributions from faecal pellets to the total amino acid flux cannot, however, be distinguished from the amino acid composition. However, zooplankton faecal pellets are not a major contributor to total mass flux in Kiel Bight (Smetacek 1980).

\section{Amino acid nitrogen/chlorophyll ratios}

Packard \& Dortch (1975) suggested the use of protein-N/chlorophyll ratios to differentiate between detrital and living particulate material. Low values such as those found in upwelling regions indicated a contribution of approximately $65 \%$ from living biomass to the total particulate pool whereas for oceanic regions high values were found indicating a contribution of $20 \%$ only. For drifting sediment traps deployed at the bottom of the euphotic zone in the Bransfield Strait, amino acid nitrogen/chlorophyll (AA-N/chl) ratios of 2.48 and 2.17 can be calculated (Liebezeit 1985a, B. von Bodungen pers. comm.).

It is of interest to note here that one trap collected mainly faeces from Euphasia superba whereas in the other only intact diatoms were found. The close agreement between both ratios indicates that grazing did not change the biochemical composition significantly. Whether this also holds true for copepods - the main zooplankton of Kiel Bight - has still to be established.

Although our ratios are not directly comparable to those of Packard \& Dortch (1975), similar trends are observed. During winter, when phytoplankton standing stock is low and the detrital component of the particulate matter is relatively large, these ratios are high. During the sedimentation of the spring bloom, decreasing values are observed (Fig. 2, Table 1). Both

Table 1. Fluxes and composition of amino acids in Kiel Bight from February to June 1980. AA-C: amino acid carbon; AA-N: amino acid nitrogen; ASP: aspartic acid; GLU: glutamic acid; SER: serine; GLY; glycine; THR: threonine; ALA: alanine. Mean values $\pm 1 \mathrm{SD}$

\begin{tabular}{|c|c|c|c|}
\hline Compound & Winter & Spring bloom & Summer \\
\hline$A A-C\left(m g m^{-2} d^{-1}\right)$ & $18.7 \pm 13.7$ & $152.9 \pm 112.1$ & $15.5 \pm 17.9$ \\
\hline $\mathrm{AA}-\mathrm{N}\left(\mathrm{mg} \mathrm{m}^{-2} \mathrm{~d}^{-1}\right)$ & $8.1 \pm 5.7$ & $64.4 \pm 55.2$ & $7.3 \pm 7.0$ \\
\hline$\%$ POC & $7.6 \pm 1.6$ & $14.9 \pm 8.7$ & $15.1 \pm 6.4$ \\
\hline$\%$ PON & $27.3 \pm 6.1$ & $43.8 \pm 21.3$ & $45.2 \pm 18.8$ \\
\hline $\mathrm{AA}-\mathrm{N} / \mathrm{CHL}$ & $8.5 \pm 6.3$ & $2.3 \pm 1.8$ & $15.1 \pm 21.0$ \\
\hline \multicolumn{4}{|l|}{ Molar percentages } \\
\hline ASP & $13.8 \pm 7.9$ & $21.5 \pm$ & $17.3 \pm 4.3$ \\
\hline GLU & $9.8 \pm 3.9$ & $10.8 \pm \quad 3.2$ & $13.7 \pm 3.5$ \\
\hline SER & $13.3 \pm 2.8$ & $10.6 \pm$ & $10.4 \pm 2.4$ \\
\hline GLY/THR & $29.9 \pm 18.1$ & $14.0 \pm 6.8$ & $17.7 \pm 6.8$ \\
\hline ALA & $7.0 \pm 3.3$ & $8.5 \pm 3.1$ & $9.0 \pm 4.2$ \\
\hline
\end{tabular}


high and low values are found during summer, the latter being linked to the blooms of dinoflagellates and Mesodinium rubrum (Fig. 2).

\section{Origin of detrital material}

Packard \& Dortch (1975) connected high protein-N/ chl values with a high contribution from detrital sources. The same holds true for the present AA-N/chl ratios. Thus, the summer values would indicate that a large detrital component is present in sumner which, however, gradually loses its initial importance (Fig. 2). The origin of this detrital material might be sought in the clay-sized fraction of sediment resuspended earlier in March. This fine fraction is commonly associated with a high content of organic matter with a major contribution of amino acids (P. J. Müller pers. comm.). Especially the presence of increased levels of aspartic and glutamic acids (Table 1) argues for a significant contribution of sedimentary material. However, Honjo et al. (1982) and Deuser et al. (1983) have shown that during sedimentation of phytoplankton blooms the water column is swept clear of detrital material as well. Since there is no a priori reason to assume why this mechanism should not be operative in Kiel Bight, other factors must be responsible for the observed presence of detritus.

Since the trap was deployed below the pycnocline, which established itself in May around $10 \mathrm{~m}$ water depth, subpycnocline processes such as restricted sediment resuspension or lateral water mass transport appear to be the controlling factors. If the observed phenomena are due to the former process then this should also be seen in the relative contribution of organic carbon to the total mass flux. During summer, high AA-N/chl ratios are generally associated with a high carbon content quite contrary to the settling of resuspended sediment in March (Fig. 2; Peinert et al. 1982). Furthermore, both AA-N and AA-C contributions are similarly high indicating the relative freshness of the organic material. A significant influx from zooplankton faecal pellets can also be ruled out. Thus influx of different water masses below the pycnocline remains as the only plausible explanation. From the data available this cannot positively be established since salinity/temperature measurements during the investigation period were made only at weekly invervals, whereas the sedimentation events occurred in much shorter periods. From continuous current measurements at $18 \mathrm{~m}$ water depth at the site of sediment trap deployment from 1975-1978, it has been shown that even after density stratification, current direction and speed can change dramatically within extremly short time spans (Rumohr, 1979) thus lending support to the second explanation given above.

\section{CONCLUSIONS}

Although absolute amino acid fluxes in summer were similar to winter values, considerably higher contrubutions to the POC and PON pools were found (Table 1). This implies that a significant amount of freshly produced material is transported to deeper water layers. Haug et al. (1973) reported for a diatom/ dinoflagellate succession a marked increase in carbohydrate content while both amino acids and lipid concentrations decreased only marginally. Nutrient limitation, which generally occurs in Kiel Bight during summer, will lead to a preferential synthesis of carbohydrates and/or lipids (Morris 1981). It can thus be assumed that besides amino acids other freshly produced and non-degraded material will reach the sea bottom even after density stratification.

These findings have some important bearings on the annual carbon budget of benthic heterotrophs. Graf et al. $(1982,1984)$ calculated from benthic heat production measurements that input from the phytoplankton spring bloom can only account for 15 to $25 \%$ of the annual requirements of the benthic fauna at $21 \mathrm{~m}$ water depth in Kiel Bight. These authors suggested benthic primary producers as a possible source of the missing carbon. Utilisation of microphytobenthos might play a significant role at shallower water depths. For deeper layers, however, material of macroalgal origin has to be considered as a major contributor to the benthic carbon budget. This is in accordance with findings of Liebezeit (1985b) who calculated that approximately $75 \%$ of the carbohydrate carbon in the upper sediment layers at 25 and $28 \mathrm{~m}$ in Kiel Bight was derived from macroalgal sources.

Macroalgae themselves contain little protein (Fowden 1962). Attached epifauna and -flora might have higher protein content; however, significant inputs from these sources requires maceration by physical processes which were not encountered in summer 1980.

From the present results it can be concluded that even during periods of low total sedimentation, material of a high nutritional quality reaches the seafloor in bursts. This together with yet unidentified sources of organic material allows the benthic heterotrophs to maintain their metabolism at a similar or even increased rate as during bloom sedimentation (Graf et al. 1982, 1984).

The quantitative importance of summer sedimentation for a benthic energy budget cannot be assessed from the present data due to the difficulties in source 
identification. These data do, however, show that for comprehensive budget calculations not only carbon but also nitrogen and phosphorus fluxes as well as the nutritional value of the sedimented material have to be taken into account.

Acknowledgements. We are indebted to the plankton group of the former Sonderforschungsbereich 95 at Kiel University, especially to R. Peinert, for supplying the samples and for many valuable discussions. Secretarial assistance by $D$. Pieper is gratefully acknowledged.

\section{LITERATURE CITED}

Billett, D. S. M., Lampitt, R. S., Rice, A. L., Mantoura, R. F. C. (1983). Seasonal sedimentation of phytoplankton to the deep-sea benthos. Nature, Lond. 302: 520-522

Bölter, M., Dawson, R. (1982). Heterotrophic utilization of biochemical compounds in Antarctic waters. Neth. J. Sea Res. 16: 315-332

Dawson, R, Liebezeit, G. (1983). Determination of amino acids and carbohydrates. In: Grasshoff, K., Kremling, K., Ehrhardt, M. (ed.) Methods of seawater analysis. Verlag Chemie, Weinheim, p. 319-340

Deuser, W. G., Ross, E. H. (1980). Seasonal change in the flux of organic carbon to the deep Sargasso Sea. Nature, Lond. 283: 364-365

Deuser, W. G., Brewer, P. G., Jickells, T. D., Commeau, P. D. (1983). Biological control of the removal of abiogenic particles from the surface ocean. Science 219: 388-391

Edler, L. (1979). Recommendations on methods for marine biological studies in the Baltic Sea: Phytoplankton and chlorophyll. Baltic Marine Biologists Publ. 5: 1-38

Fowden, L. (1962). Amino acids and proteins. In: Lewin, R. A. (ed.) Physiology and biochemistry of algae. Academic Press, New York, p. 189-209

Gagosian, R. B., Stuermer, D. H. (1977). The cycling of biogenic compounds and their diagenetically transformed products in seawater. Mar Chem. 5: 605-632

Graf, G., Bengtsson, W., Diesner, U., Schulz, R., Theede, H (1982). Benthic response to sedimentation of spring phytoplankton bloom: process and budget. Mar. Biol. 67: 201-208

Graf, G., Bengtson, W., Faubel, A., Meyer-Reil, L.-A., Schulz, R., Theede, H., Thiel, H. (1984). The importance of the spring phytoplankton bloom for the benthic system of Kiel Bight. Rapp. P.-v. Réun. Cons. int. Explor. Mer. 183: $136-143$

Haug, A., Myklestad, S., Sakshaug, E. (1973). Studies on the phytoplankton ecology of the Trondheimsfjord. I. The chemical composition of phytoplankton populations. J. exp. mar. Biol. Ecol. 11: 15-26

Hendrikson, P. (1976). Abbauraten von organischen Kohlenstoff im Seston und in Sinkstoffen der Kieler Bucht. Kieler Meeresforsch (Sonderh.) 3: 105-119

Honjo, S., Manganini, S. J., Cole, J. J. (1982). Sedimentation of biogenic matter in the deep ocean. Deep Sea Res. 29: $609-625$
Ittekkot, V., Deuser, W. G., Degens, E. T. (1984a). Seasonality in the fluxes of sugars, amino acids, and amino sugars to the deep ocean: Sargasso Sea. Deep Sea Res. 29: $1057-1070$

Ittekkot, V., Degens, E. T., Honjo, S. (1984b). Seasonality in the fluxes of sugars amino acids, and amino sugars to the deep ocean: Panama Basin. Deep Sea Res. 29: 1071-1083

Lampitt, R. S. (1985). Evidence for the seasonal deposition of detritus to the deep-sea floor and its subsequent resuspension. Deep Sea Res. 32: 885-897

Lee, C., Cronin, C. (1982). The vertical flux of particulate organic nitrogen in the sea: decomposition of amino acids in the Peru upwelling area and the equatorial Atlantic. J. mar. Res. 40: 227-251

Lee, C., Cronin, C. (1984). Particulate amino acids in the sea: effects of primary productivity and biological decomposition. J. mar. Res. 42: 1075-1097

Lee, C., Wakeham, S. G., Farrington, F. W. (1983). Variations in the composition of particulate organic matter in a timeseries sediment trap. Mar. Chem. 13: 181-194

Liebezeit, G. (1985a). Residual amino acid fluxes in the upper water column of the Bransfield Strait. Oceanologica Acta 8: $59-65$

Liebezeit, G. (1985b). Pelagic and benthic sources of sedimentary carbohydrates in a shallow water environment - Kiel Bight, Baltic. Mar. Geol. (in press)

Liebezeit, G., Dawson, R. (1981). Isoindole derivatives of amino acids for HPLC separations - effect of reaction $\mathrm{pH}$ and time on fluorescence yield. J. High Resolut. Chromatogr. Chromatogr. Commun. 4: 354-356

Lorenzen, C. J. (1967). Determination of chlorophyll and pheopigments: spectrophotometric measurements. Limnol. Oceanogr. 12: 343-346

Morris, I. (1981). Photosynthetic products, physiological state, and phytoplankton growth. Can. Bull. Fish. Aquat. Sci. 210: 83-102

Packard, T. T., Dortch, Q. (1975). Particulate protein-nitrogen in North Atlantic surface waters. Mar. Biol. 33: 347-354

Peinert, R., Saure, A., Stegmann, P., Stienen, C., Haardt, H., Smetacek, V. (1982). Dynamics of primary production and sedimentation in a coastal ecosystem. Neth. J. Sea Res. 16: 276-289

Rumohr, H. (1979). Hydrographische Dauerregistrierungen bei Boknis Eck (20 m I). Westliche Ostsee von 1975-1978. Reports Sonderforschungsbereich 95, Universität Kiel, 42, p. $1-59$

Schumann, M. (1983). Die Zusammensetzung partikulären organischen Materials aus der Kieler Bucht und dessen Verwertung durch Mytilus edulis. Ph. D. thesis, Univ. of Kiel

Smetacek, V. S. (1980). Zooplankton standing stock, copepod faecal pellets and particulate detritus in Kiel Bight. Estuar. coast. mar. Sci. 11: 477-490

Smetacek, V. S., von Bodungen, B., Knoppers, B., Peinert, R., Pohelenne, F., Stegmann, P., Zeitschel, B. (1984). Seasonal stages characterizing the annual cycle of an inshore pelagic system. Rapp. P.-v. Réun. Cons. Int. Explor. Mer 183: $126-135$

Zeitzschel, B., Diekmann, P., Uhlmann, L. (1978). A new multi-sample sediment trap. Mar. Biol. 45: 285-288 